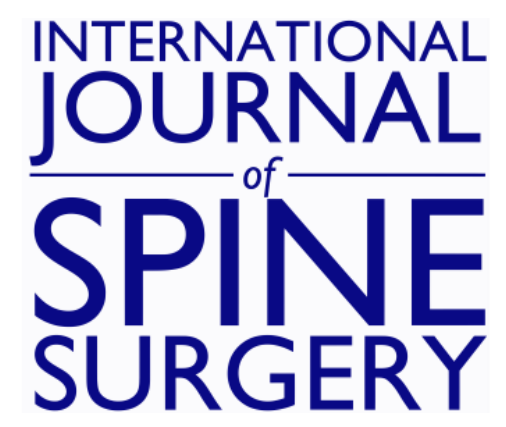

\title{
Sacroiliac Joint Fusion Minimally Affects Adjacent Lumbar Segment Motion: A Finite Element Study
}

Derek P. Lindsey, Ali Kiapour, Scott A. Yerby and Vijay K. Goel

Int J Spine Surg 2015, 9 ()

doi: https://doi.org/10.14444/2064

http://ijssurgery.com/content/9/64

This information is current as of April 26, 2023.

Email Alerts Receive free email-alerts when new articles cite this article. Sign up at:

http://ijssurgery.com/alerts

The International Journal of Shing Surgerih 2397 Waterbury Circle, Suite 1,

Aurora, IL 60504, Phone: +1-630-375-1432

(C) 2015 ISASS. All Rights Reserved. 


\section{Sacroiliac Joint Fusion Minimally Affects Adjacent Lumbar Segment Motion: A Finite Element Study}

Derek P. Lindsey, MS, ${ }^{1}$ Ali Kiapour, PhD, ${ }^{2}$ Scott A. Yerby, PhD, ${ }^{1}$ Vijay K. Goel, PhD ${ }^{2}$

${ }_{1} S I-B O N E$, Inc. San Jose, CA, 2 Engineering Center for Orthopaedic Research Excellence (E-CORE), Departments of Bioengineering and Orthopaedic Surgery, Colleges of Engineering and Medicine, University of Toledo, Toledo, $\mathrm{OH}$

\section{Abstract}

Background

Adjacent segment disease is a recognized consequence of fusion in the spinal column. Fusion of the sacroiliac joint is an effective method of pain reduction. Although effective, the consequences of sacroiliac joint fusion and the potential for adjacent segment disease for the adjacent lumbar spinal levels is unknown. The objective of this study was to quantify the change in range of motion of the sacroiliac joint and the adjacent lumbar spinal motion segments due to sacroiliac joint fusion and compare these changes to previous literature to assess the potential for adjacent segment disease in the lumbar spine.

Methods

An experimentally validated finite element model of the lumbar spine and pelvis was used to simulate a fusion of the sacroiliac joint using three laterally placed triangular implants (iFuse Implant System, SI-BONE, Inc., San Jose, CA). The range of motion of the sacroiliac joint and the adjacent lumbar spinal motion segments were calculated using a hybrid loading protocol and compared with the intact range of motion in flexion, extension, lateral bending, and axial rotation.

Results

The range of motions of the treated sacroiliac joints were reduced in flexion, extension, lateral bending, and axial rotation, by $56.6 \%, 59.5 \%, 27.8 \%$, and $53.3 \%$, respectively when compared with the intact condition. The stiffening of the sacroiliac joint resulted in increases at the adjacent lumbar motion segment (L5-S1) for flexion, extension, lateral bending, and axial rotation, of $3.0 \%, 3.7 \%, 1.1 \%$, and $4.6 \%$, respectively.

\section{Conclusions}

Fusion of the sacroiliac joint resulted in substantial ( $>50 \%)$ reductions in flexion, extension, and axial rotation of the sacroiliac joint with minimal $(<5 \%)$ increases in range of motion in the lumbar spine. Although the predicted increases in lumbar range of motion are minimal after sacroiliac joint fusion, the long-term clinical results remain to be investigated.

KEYWORDS: SACROILIAC JOINT DYSFUNCTION, FUSION, BIOMECHANICS, MINIMALLY INVASIVE SURGERY, FINITE ELEMENT ANALYSIS, ADJACENT SEGMENT DISEASE

VOLUME 9 ARTICLE 64 DOI: 10.14444/2064

\section{Introduction}

Low back pain is currently the largest contributor to disability worldwide. ${ }^{1}$ The global burden of low back pain has significantly increased from 1990 to 2010. In 2010, an estimated 83 million well-years of life were lost to low back pain. ${ }^{2}$ Potential pain generators for low back pain include the lumbar spine, hip, and the sacroiliac (SI) joint. ${ }^{3}$

Arthrodesis of the spine was pioneered by Hibbs and
Albee for the treatment of Pott's disease in 1911., Since that time, spinal arthrodesis has been employed throughout the spinal column with four principle motives: 1) reestablish clinical stability, 2) maintain correction, 3) prevent progression of deformity, and 4) stiffen a spinal segment to alleviate pain. ${ }^{6}$ A review by Phillips et al. showed that lumbar spine fusion successfully decreases the pain and disability from degeneration of a lumbar motion segment. ${ }^{7}$ Hansson et al. compared health-related quality of life measurements for spinal fusion to other 
elective orthopedic procedures (total knee replacement and total hip replacement) and found larger improvements for spinal fusion. ${ }^{8}$ Even though lumbar spine fusion successfully reduces pain and disability, there are reports of increased degeneration and disease at the adjacent lumbar segments. ${ }^{9}$ Adjacent segment disease (ASD) following lumbar arthrodesis may require revision surgery at the adjacent segments - Sears et al. reported a mean annual incidence of $2.5 \%$ of patients requiring surgery. ${ }^{10}$ In this context, ASD is used to describe any abnormal process in a motion segment (e.g. disc degeneration, stenosis, etc.) next to the fusion level. ${ }^{11}$

Various risk factors for ASD have been identified including instrumentation, injury to the facet of the adjacent level, fusion length, sagittal alignment, and pre-existing disc degeneration. ${ }^{11}$ Of these factors, instrumentation, fusion length, and sagittal alignment can have the most significant effect on biomechanical stresses at the adjacent level. Rigid fixation of a motion segment increases the treated segment stiffness, while increasing the stresses on the adjacent levels. ${ }^{12,13}$ In a cadaveric study of three lumbosacral fusion techniques, all techniques resulted in increased stresses on the adjacent unfused lumbar segments. ${ }^{14}$

While the spine is the most significant source of low back pain, the SI joint has been recognized as a pain generator in $14.5 \%$ to $22.55 \%$ of patients with low back pain. ${ }^{3,15} \mathrm{SI}$ joint fusion may be required if nonoperative treatments (e.g. anti-inflammatory medications, physical therapy, steroid injections) fail. ${ }^{15,16}$ Surgical treatment of the SI joint can be performed using either open or minimally invasive surgical (MIS) techniques. Recent studies comparing the two fusion techniques found the MIS procedure resulted in larger improvements in Oswestry Disability Index (ODI) and pain relief, as well as shorter surgical times and hospital stays. ${ }^{17,19}$ Long-term results of a MIS procedure have shown that the improvements have been maintained with no evidence of implant loosening or long-term complications. ${ }^{20}$

Although MIS SI joint fusion has been shown to be clinically effective, ${ }^{18}$ the potential for adjacent segment disease is unknown. The purpose of this study was to quantify the changes at the adjacent lumbar motion segments after SI joint fusion and compare them to the changes reported for lumbar arthrodesis procedures that have increased risk for ASD. To investigate the changes, a minimally invasive SI joint fusion procedure was simulated in a threedimensional, experimentally validated lumbar spinepelvis finite element model; finite element modelling is a good tool to estimate the limited range of motion (ROM) observed in the SI joint $\left(\sim 2^{\circ}\right) .^{21,22}$ The angular motions of the SI joint and lumbar motion segments were computed and compared between the intact and treated conditions. The potential for ASD was assessed by comparing the changes in motion of the lumbar spine with previous lumbar arthrodesis studies of ASD.

\section{Materials and Methods}

This experimentally validated finite element mod$\mathrm{el}^{23,24}$ has been used previously to evaluate surgical fusion of the lumbar spine and the effects of leglength discrepancy. ${ }^{24,25}$ The model was comprised of the lumbar spine, pelvis, and both femurs and contained 60,126 elements and 77,540 nodes. The model was developed from a computed tomography (CT) scan of a young male pelvis without any irregularities or severe degeneration. Material properties for the bone, ligaments and joints are based upon the previous study (Table 1$).{ }^{24}$ Further information about the model can be found in Ivanov et al. ${ }^{24}$ All models were analyzed using ABAQUS 6.11 software (Simulia, Providence, RI). Loading of the model was simulated using double-leg stance. To constrain the model, the caudal ends of the femur were fixed in all degrees of freedom and the femoral head was fixed to the acetabulum to prevent any rotation between the pelvis and the femur. For the intact condition, a $400 \mathrm{~N}$ follower load was initially applied then a $10 \mathrm{~N}-\mathrm{m}$ moment was applied to simulate physiological flexion, extension, left and right lateral bending, and left and right axial rotation to determine the range of motions. For the treated condition, a hybrid loading protocol was used $;^{26}$ this involved gradually increasing the bending moment at the cranial end of the segment until the overall motion of the segment matched that of the intact under a $10 \mathrm{~N}-\mathrm{m}$ bending moment. Motions were calculated at each motion segment between L1 and S1 (e.g. L1-L2, L2-L3), and 
the left (treated) SI joint in all models. For comparison purposes, the left and right bending motions for each motion segment were combined into a single value (lateral bending); likewise, the left and right rotation motions for each motion segment were combined into a single value (axial rotation).

SI joint fusion using three triangular titanium plasma spray (TPS) coated implants (iFuse Implant $7.0 \mathrm{~mm}$; SI-BONE, Inc., San Jose, CA) was simulated across the left joint according to the manufacturer's recommendation (Figure 1). Lateral placement of the implants was simulated using a trans-articular technique (Figure 1) ${ }^{27}$ Briefly, this technique places the implants parallel in the sacral outlet view and convergent in the sacral inlet view; placement is optimized to cross the hyaline cartilage portion of the SI joint. Surgically, the implants are placed by a pin, drill, broach, and impaction procedure. Impaction is required to insert the implants to engage the press fit between the TPS coating on the implant and the broached hole. The implants in this model consisted of the inner core of Ti6Al4V ELI $(\mathrm{E}=115 \mathrm{GPa})$ without the TPS coating; implant lengths were: superior, $55 \mathrm{~mm}$; middle, 45 ; inferior, $50 \mathrm{~mm}$. To simulate the press fit on each implant, a mating part with a longitudinal cut was created within the model (Figure 2). The mating part's properties were that of the surrounding pelvis model, including the SI joint gap and the bone material properties (Figure 2). To determine the press fit, a separate smaller mating part (to simulate the overlap of the press fit) was modeled and the force required to open the longitudinal cut such that an implant could be inserted was determined. In the full lumbo-pelvic model, the press fit between the bone and implant was simulated by applying the calculated force to close the longitudinal cut.

The applied moments were compared between the intact and treated models. The changes in range of motion between the intact and treated models were calculated and compared for both the SI joint and adjacent lumbar segments.

\section{Results}

Loading of the intact model resulted in L1 - pelvis motions of $28.26^{\circ}$ in flexion, $14.27^{\circ}$ in extension, $52.84^{\circ}$ in lateral bending, and $29.31^{\circ}$ in axial rotation. Loading the treated model (to the intact angles) re-

Table 1. Material Properties of Components of the Spinal and Pelvic Finite Element Model.

\begin{tabular}{|c|c|c|c|}
\hline Component & $\begin{array}{l}\text { Element } \\
\text { Formulation }\end{array}$ & $\begin{array}{l}\text { Young's Modulus } \\
\text { (MPa) }\end{array}$ & $\begin{array}{l}\text { Poisson's } \\
\text { Ratio }\end{array}$ \\
\hline \multicolumn{4}{|l|}{$\begin{array}{l}\text { Bony } \\
\text { Structure }\end{array}$} \\
\hline $\begin{array}{l}\text { Vertebral } \\
\text { Cortical Bone }\end{array}$ & $\begin{array}{l}\text { Isotropic, elastic hex } \\
\text { elements }\end{array}$ & 12,000 & 0.3 \\
\hline $\begin{array}{l}\text { Vertebral } \\
\text { Cancellous } \\
\text { Bone }\end{array}$ & $\begin{array}{l}\text { Isotropic, elastic hex } \\
\text { elements }\end{array}$ & 100 & 0.2 \\
\hline $\begin{array}{l}\text { Posterior } \\
\text { Cortical Bone }\end{array}$ & $\begin{array}{l}\text { Isotropic, elastic hex } \\
\text { elements }\end{array}$ & 12,000 & 0.3 \\
\hline $\begin{array}{l}\text { Posterior } \\
\text { Cancellous } \\
\text { Bone }\end{array}$ & $\begin{array}{l}\text { Isotropic, elastic hex } \\
\text { elements }\end{array}$ & 100 & 0.2 \\
\hline $\begin{array}{l}\text { Pelvic } \\
\text { Cortical Bone }\end{array}$ & $\begin{array}{l}\text { Isotropic, elastic hex } \\
\text { elements }\end{array}$ & 17,000 & 0.3 \\
\hline $\begin{array}{l}\text { Pelvic } \\
\text { Cancellous } \\
\text { Bone }\end{array}$ & $\begin{array}{l}\text { Isotropic, elastic hex } \\
\text { elements }\end{array}$ & 10 & 0.2 \\
\hline \multicolumn{4}{|l|}{$\begin{array}{l}\text { Intervertebral } \\
\text { Disc }\end{array}$} \\
\hline $\begin{array}{l}\text { Annulus } \\
\text { (ground) }\end{array}$ & $\begin{array}{l}\text { Neo-Hookean, hex } \\
\text { elements }\end{array}$ & $\mathrm{C} 10=0.348, \mathrm{D} 1=0.3$ & \\
\hline $\begin{array}{l}\text { Annulus } \\
\text { (fiber) }\end{array}$ & Rebar & $357-500$ & 0.3 \\
\hline $\begin{array}{l}\text { Nucleus } \\
\text { Pulposus }\end{array}$ & $\begin{array}{l}\text { Incompressible fluid, } \\
\text { cavity elements }\end{array}$ & 1 & 0.499 \\
\hline \multicolumn{4}{|l|}{ Ligaments } \\
\hline $\begin{array}{l}\text { Anterior } \\
\text { Longitudinal }\end{array}$ & $\begin{array}{l}\text { Tension-only, Truss } \\
\text { elements }\end{array}$ & $\begin{array}{l}7.8(<12 \%) \\
20.0(>12 \%)\end{array}$ & 0.3 \\
\hline $\begin{array}{l}\text { Posterior } \\
\text { Longitudinal }\end{array}$ & $\begin{array}{l}\text { Tension-only, Truss } \\
\text { elements }\end{array}$ & $\begin{array}{l}10.0(<11 \%) \\
20.0(>11 \%)\end{array}$ & 0.3 \\
\hline $\begin{array}{l}\text { Ligamentum } \\
\text { Flavum }\end{array}$ & $\begin{array}{l}\text { Tension-only, Truss } \\
\text { elements }\end{array}$ & $\begin{array}{l}15.0(<6.2 \%), \\
19.5(>6.2 \%)\end{array}$ & 0.3 \\
\hline Intertransverse & $\begin{array}{l}\text { Tension-only, Truss } \\
\text { elements }\end{array}$ & $\begin{array}{l}10.0(<18 \%) \\
58.7(>18 \%)\end{array}$ & 0.3 \\
\hline Interspinous & $\begin{array}{l}\text { Tension-only, Truss } \\
\text { elements }\end{array}$ & $\begin{array}{l}10.0(<14 \%) \\
11.6(>14 \%)\end{array}$ & 0.3 \\
\hline Supraspinous & $\begin{array}{l}\text { Tension-only, Truss } \\
\text { elements }\end{array}$ & $\begin{array}{l}8.0(<20 \%) \\
15.0(>20 \%)\end{array}$ & 0.3 \\
\hline Capsular & $\begin{array}{l}\text { Tension-only, Truss } \\
\text { elements }\end{array}$ & $\begin{array}{l}7.5(<25 \%) \\
32.9(>25 \%)\end{array}$ & 0.3 \\
\hline Anterior SI & $\begin{array}{l}\text { Tension-only, Truss } \\
\text { elements }\end{array}$ & $\begin{array}{l}125(<2.5 \%) \\
175(>5 \%), \\
325(>10 \%) \\
316(>15 \%)\end{array}$ & 0.3 \\
\hline $\begin{array}{l}\text { Inner posterior } \\
\text { SI }\end{array}$ & $\begin{array}{l}\text { Tension-only, Truss } \\
\text { elements }\end{array}$ & $\begin{array}{l}43(<2.5 \%), 61(>5 \%), \\
113(>10 \%), \\
110(>15 \%)\end{array}$ & 0.3 \\
\hline $\begin{array}{l}\text { Outer } \\
\text { posterior SI }\end{array}$ & $\begin{array}{l}\text { Tension-only, Truss } \\
\text { elements }\end{array}$ & $\begin{array}{l}150(<2.5 \%), \\
211(>5 \%), \\
391(>10 \%), \\
381(>15 \%)\end{array}$ & 0.3 \\
\hline Intraosseus & $\begin{array}{l}\text { Tension-only, Truss } \\
\text { elements }\end{array}$ & $\begin{array}{l}40(<2.5 \%), 57(>5 \%), \\
105(>10 \%), \\
102(>15 \%)\end{array}$ & 0.3 \\
\hline Sacrospinous & $\begin{array}{l}\text { Tension-only, Truss } \\
\text { elements }\end{array}$ & $\begin{array}{l}304(<2.5 \%) \\
428(>5 \%), \\
792(>10 \%) \\
771(>15 \%)\end{array}$ & 0.3 \\
\hline Sacrotuberous & $\begin{array}{l}\text { Tension-only, Truss } \\
\text { elements }\end{array}$ & $\begin{array}{l}326(<2.5 \%) \\
458(>5 \%), \\
848(>10 \%) \\
826(>15 \%)\end{array}$ & 0.3 \\
\hline \multicolumn{4}{|l|}{ Joint } \\
\hline $\begin{array}{l}\text { Apophyseal } \\
\text { Joints }\end{array}$ & $\begin{array}{l}\text { Non-linear Soft } \\
\text { contact, GAPPUNI } \\
\text { elements }\end{array}$ & - & - \\
\hline $\begin{array}{l}\text { Sacroiliac } \\
\text { Joints }\end{array}$ & $\begin{array}{l}\text { Soft Contact with } \\
\text { Exponential } \\
\text { Behavior }\end{array}$ & - & - \\
\hline
\end{tabular}

Downloaded from http://ijssurgery.com/ by guest on April 26, 2023 
quired moments of $10.54 \mathrm{~N}-\mathrm{m}$ for flexion, $10.31 \mathrm{~N}-\mathrm{m}$ for extension, $10.15 \mathrm{~N}-\mathrm{m}$ for lateral bending, and $10.58 \mathrm{~N}-\mathrm{m}$ for axial rotation. The treated model moments were increased by $5.4 \%$ for flexion, $3.1 \%$ for extension, $1.5 \%$ for lateral bending, and $5.8 \%$ for axial rotation.

The implants reduced the SI joint range of motion in all directions (Figure 3; Table 2). The SI joint motion was reduced by $56.6 \%$ in flexion, $59.5 \%$ in extension, $27.8 \%$ in lateral bending, and $53.3 \%$ in axial rotation.

The range of motions at the adjacent lumbar segments were increased in all loadings, with the largest changes occurring closest to the treated motion segment (Figure 3; Table 2). At the adjacent segment (L5-S1) the motion was increased by $3.0 \%$, in flexion, $3.7 \%$ in extension, $1.1 \%$ in lateral bending, and $4.6 \%$ in axial rotation. At L1-L2 the motion was increased by

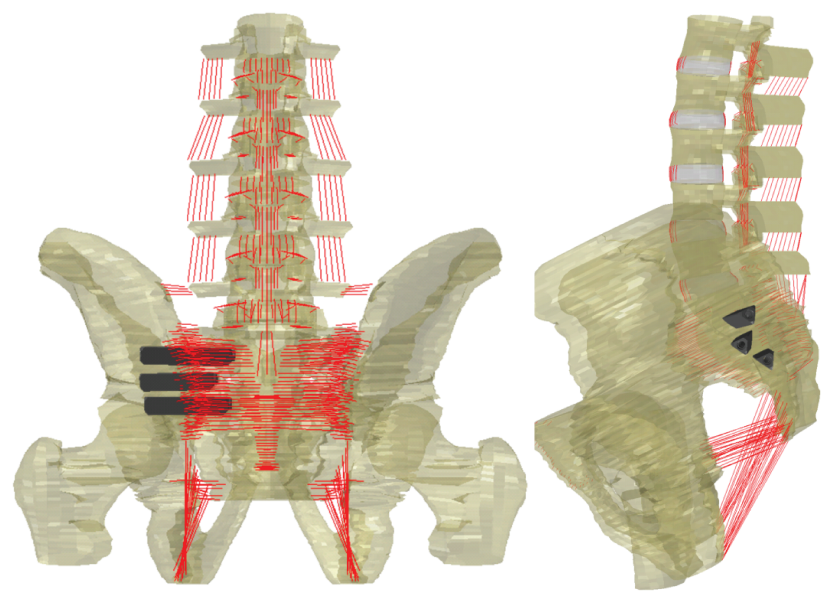

Fig. 1. Posterior (left) and lateral (right) model views showing trans-articular placement of three sacroiliac joint fusion implants in a lumbo-pelvic finite element model.

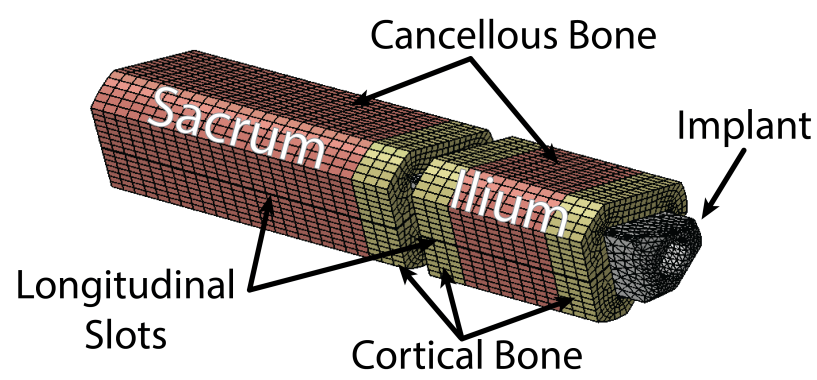

Fig. 2. A close-up view of the bone-implant interface. The mating piece is composed of both cancellous and cortical bone that matches the material properties of the adjoining ilium and sacrum. The press fit between the bone and implant was simulated by applying a closing force across the longitudinal slots.
$1.0 \%$ in flexion, $2.9 \%$ in extension, $0.1 \%$ in lateral bending, and $0.3 \%$ in axial rotation.
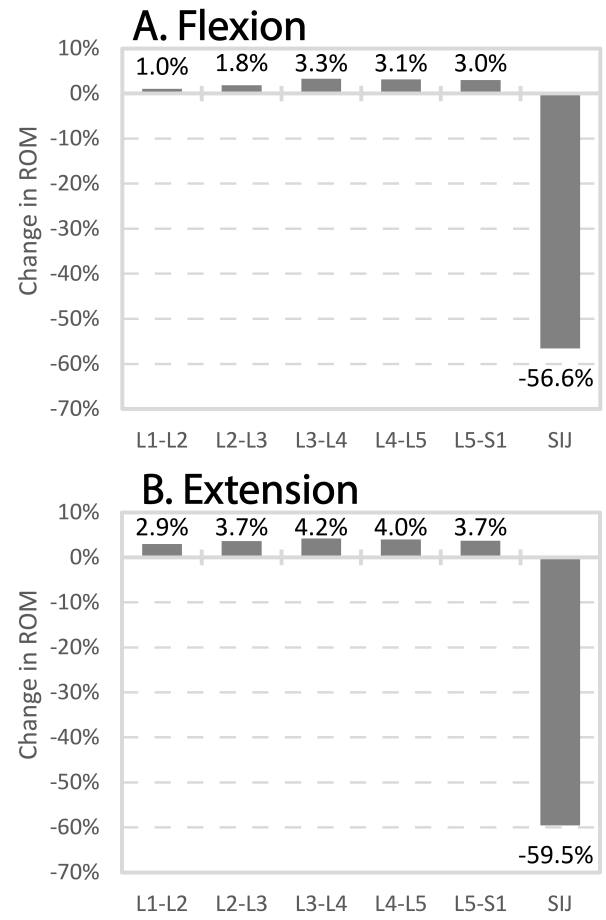

C. Lateral Bending

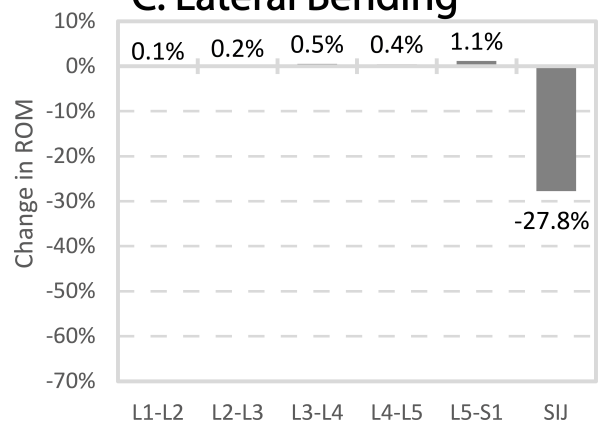

D. Axial Rotation

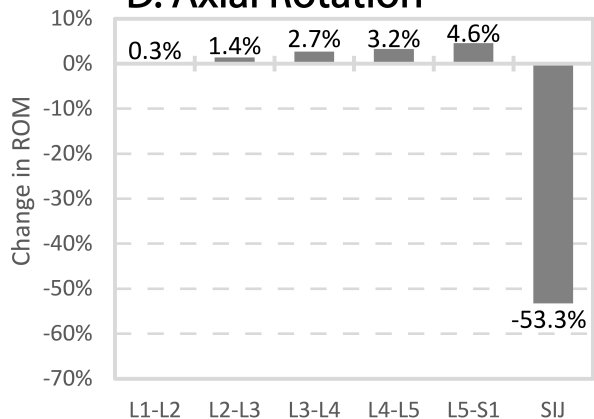

Fig. 3. Change in range of motion (\%) after placement of three sacroiliac joint fusion implants for four directions of loading: A) Flexion, B) Extension, C) Lateral Bending, and D) Axial Rotation. Range of motion was calculated using a hybrid loading protocol in a finite element model. 


\section{Discussion}

The results of the current study show that the hybrid loading protocol required slightly larger applied moments to flex the treated specimen to the intact angular motion. As noted in previous studies, rigid fixation of a motion segment increases the overall construct stiffness. ${ }^{13,24}$ Ivanov et al. reported moment increases of 46 - 88\% after a single level lumbar fusion. ${ }^{24}$ Kyaw et al. reported moment increases of 122 - 469\% after rigid fixation in a degenerative lumbar model. ${ }^{13}$ The applied moments in this study were increased much smaller amounts $(<6 \%)$ - suggesting that fusion of the SI joint does not substantially stiffen the lumbo-pelvic construct.

The finite element model tested in this study showed SI joint motions in the intact and treated conditions to be in agreement with results found in a prior experimental study. ${ }^{27}$ Although the models are similar, the current finite element model has some differences compared with the previous cadaver experiment: double-leg stance, follower load, and larger moment (10 N-m vs $7.5 \mathrm{~N}-\mathrm{m})$. These differences are likely offsetting for the SI joint as the use of a follower load and double-leg stance likely increase stability, while the use of a larger applied moment would increase the ROM. In the present model, the calculated SI joint motions for the intact model are similar to those in the previous cadaveric study in flexionextension $\left(1.454^{\circ} \pm 0.675^{\circ}\right)$, lateral bending $\left(0.830^{\circ} \pm\right.$ $\left.0.412^{\circ}\right)$, and axial rotation $\left(1.207^{\circ} \pm 0.558^{\circ}\right) .{ }^{27}$ For the

Table 2. Flexion, extension, lateral bending, and axial rotational range of motions for intact and treated sacroiliac (SI) joint. SI joints were treated with three triangular TPS coated implants using a minimally invasive surgical procedure.

\begin{tabular}{|l|l|l|l|l|l|l|l|l|}
\hline \multicolumn{7}{|l|}{ Angular Range of Motion $\left(^{\circ}\right)$} \\
\hline & \multicolumn{2}{|l|}{ Flexion } & \multicolumn{2}{l|}{ Extension } & \multicolumn{2}{l|}{$\begin{array}{l}\text { Lateral } \\
\text { Bending }\end{array}$} & \multicolumn{2}{l|}{ Axial Rotation } \\
\hline Level(s) & Intact & Treated & Intact & Treated & Intact & Treated & Intact & Treated \\
\hline L1-L2 & 4.79 & 4.84 & 2.04 & 2.1 & 13.44 & 13.46 & 6.58 & 6.6 \\
\hline L2-L3 & 4.87 & 4.96 & 2.46 & 2.55 & 12.22 & 12.24 & 5.82 & 5.9 \\
\hline L3-L4 & 5.17 & 5.34 & 2.39 & 2.49 & 10.08 & 10.13 & 5.64 & 5.79 \\
\hline L4-L5 & 5.11 & 5.27 & 2.74 & 2.85 & 9.3 & 9.34 & 5.26 & 5.43 \\
\hline L5-S1 & 7.11 & 7.32 & 3.8 & 3.94 & 7.08 & 7.16 & 4.79 & 5.01 \\
\hline SI Joint & 1.22 & 0.53 & 0.84 & 0.34 & 0.72 & 0.52 & 1.22 & 0.57 \\
\hline
\end{tabular}

treated model, the previous cadaveric study used a destabilized model (sectioned pubic symphysis) to investigate two SI joint fusion implant placement techniques on SI joint motion. The reductions in motion in flexion, extension, and axial rotation of the current model are within the upper limit of the ranges reported in the previous cadaveric study; the current lateral bending results are similar to the previous cadaveric study. Even in the context of model differences and specimen variability, the agreement in motion reduction demonstrates that the current finite element model is adequately modeling the SI joint fusion procedure.

The reduction in motion at the SI joint led to minimal increases in motion at the adjacent lumbar levels. The motions of the lumbar segments in the intact model are consistent with those previously reported. ${ }^{28-30}$ The increases in adjacent segment lumbar motion after treatment in this study $(<5 \%)$ are substantially lower than those reported in the adjacent lumbar segment after lumbar fusion. In vitro studies have reported increases of $20 \%$ to $127 \%$ for the cranial adjacent motion segment after lumbar/lumbosacral fusion (Table 3)..$^{12,13}$ While placement of rigid implants markedly decreases SI joint range of motion, the overall adjacent lumbar segment effects of this diminished ROM are minimal.

Factors shown to increase the risk for ASD include surgical damage to adjacent segment structures such as the facets or local soft tissues as well as changes to the sagittal alignment. The lateral approach for this surgical technique minimizes the risk of injuring the facets or soft tissues. The surgical incision is in the

\begin{tabular}{|c|c|c|c|}
\hline \multicolumn{4}{|c|}{ Change in Cranial Segment Range of Motion } \\
\hline \multirow[b]{2}{*}{ Loading Direction } & \multicolumn{3}{|c|}{ Site of Fusion } \\
\hline & $\begin{array}{r}\text { Lumbosacral } \\
\text { (Ha 1993) }\end{array}$ & $\begin{array}{r}\text { Lumbar } \\
\text { (Kyaw 2014) }\end{array}$ & $\begin{array}{r}\text { Sacroiliac } \\
\text { (Current) }\end{array}$ \\
\hline Flexion & $88 \%$ & $20 \%$ & $3.0 \%$ \\
\hline Extension & $56 \%$ & $20 \%$ & $3.7 \%$ \\
\hline Lateral Bending & $26 \%$ & $21 \%$ & $1.1 \%$ \\
\hline Axial Rotation & $\mathrm{N} / \mathrm{A}$ & $127 \%$ & $4.6 \%$ \\
\hline
\end{tabular}


lateral buttock area well away from the L5-S1 facets. (Figure 1). This surgical technique is unlikely to result in significant change in sagittal alignment of the spine and pelvis as SI joint motion is quite small, although this remains an area open for study. The combination of the minimal increased ROM of the lumbar spine after SI joint fusion and differences in procedure decreases the probability of lumbar ASD secondary to SI joint fusion.

The use of a finite element model presents some limitations regarding the interpretation and application of the results. The model used herein represents a single patient, thus extrapolation to a larger patient population should be made with caution. The basis for this model was a young male without any irregularities or severe degeneration, which is not a typical candidate for SI joint fusion. ${ }^{20}$ Ideally, the finite element model would include all of the pertinent characteristics related to the procedure being investigated (e.g. SI joint dysfunction). Finite element models of the musculoskeletal system are complex with specific anatomy and multiple mechanical parameters for each tissue type (Table 1) and require validation with experimental data to ensure that the simulations are adequate. To our knowledge there is no specific experimental biomechanical data of a dysfunctional SI joint, although this remains an area for further research. Although the current model did not exactly simulate a dysfunctional SI joint, the intact motions are consistent with a previous in vitro study that used both male and female specimens (average age of 52 years $)^{27}$, suggesting that the biomechanics of the SI joint are being adequately modeled. Another potential limitation of this model was the simulation of the bone-implant interface; although the TPS coating could not be simulated, the interference fit was accounted for by the addition of compressive force across the mating part (Figure 2). Even though the bone-implant interface model may not exactly reproduce the in vivo situation, the reductions in motion at the SI joint reported here are in agreement with a previous experiment, ${ }^{27}$ thus, confirming this model. Another limitation is that the bone-implant interface is unable to simulate the biological response over time. Lastly, the current study only investigated three specific motions and may not be applicable to all motions that a patient may encounter during ac- tivities of daily living.

\section{Conclusions}

The results of this study demonstrate that fusion of the SI joint using a series of triangular implants substantially (>50\%) reduced SI joint range of motion in flexion, extension, and axial rotation, and minimally $(<5 \%)$ increased adjacent lumbar segment ranges of motion. The current study presents a theoretical model for assessing the potential risk of developing adjacent segment disease in the lumbar spine after SI joint fusion, as such, long-term clinical studies will be required to determine if adjacent segment disease in the lumbar spine is a complication resulting from SI joint fusion.

\section{References}

1. Hoy D, March L, Brooks P, Blyth F, Woolf A, Bain C, et al. The global burden of low back pain: estimates from the Global Burden of Disease 2010 study. Ann Rheum Dis. 2014 Jun;73(6):968-74. 2. Murray CJL, Vos T, Lozano R, Naghavi M, Flaxman AD, Michaud C, et al. Disability-adjusted life years (DALYs) for 291 diseases and injuries in 21 regions, 1990-2010: a systematic analysis for the Global Burden of Disease Study 2010. Lancet. 2012 Dec 15;380(9859):2197-223.

3. Sembrano JN, Polly DW. How often is low back pain not coming from the back? Spine. 2009 Jan 1;34(1):E27-32.

4. Hibbs RA. An operation for progressive spinal deformities: a preliminary report of three cases from the service of the orthopaedic hospital. 1911. Clin Orthop. 2007 Jul;460:17-20.

5. Albee FH. The classic. Transplantation of a portion of the tibia into the spine for Pott's disease. A preliminary report. Jama, 57: 885, 1911. Clin Orthop. 1972 Sep;87:5-8.

6. White AA, Panjabi MM. Clinical biomechanics of the spine. Philadelphia: Lippincott; 1978. 534 p.

7. Phillips FM, Slosar PJ, Youssef JA, Andersson G, Papatheofanis F. Lumbar spine fusion for chronic low back pain due to degenerative disc disease: a systematic review. Spine. 2013 Apr 1;38(7):E409-22.

8. Hansson T, Hansson E, Malchau H. Utility of

Downloaded from http://ijssurgery.com/ by guest on April 26, 2023 
spine surgery: a comparison of common elective orthopaedic surgical procedures. Spine. 2008 Dec 1;33(25):2819-30.

9. Hilibrand AS, Robbins M. Adjacent segment degeneration and adjacent segment disease: the consequences of spinal fusion? Spine J Off J North Am Spine Soc. 2004 Dec;4(6 Suppl):190S - 194S. 10. Sears WR, Sergides IG, Kazemi N, Smith M, White GJ, Osburg B. Incidence and prevalence of surgery at segments adjacent to a previous posterior lumbar arthrodesis. Spine J Off J North Am Spine Soc. 2011 Jan;11(1):11-20.

11. Park P, Garton HJ, Gala VC, Hoff JT, McGillicuddy JE. Adjacent segment disease after lumbar or lumbosacral fusion: review of the literature. Spine. 2004 Sep 1;29(17):1938-44.

12. Ha KY, Schendel MJ, Lewis JL, Ogilvie JW. Effect of immobilization and configuration on lumbar adjacent-segment biomechanics. J Spinal Disord. 1993 Apr;6(2):99-105.

13. Kyaw TA, Wang Z, Sakakibara T, Yoshikawa T, Inaba T, Kasai Y. Biomechanical effects of pedicle screw fixation on adjacent segments. Eur J Orthop Surg Traumatol Orthopédie Traumatol. 2014 Jul;24 Suppl 1:S283-7.

14. Lee CK, Langrana NA. Lumbosacral spinal fusion. A biomechanical study. Spine. 1984

Sep;9(6):574-81.

15. Bernard TN, Kirkaldy-Willis WH. Recognizing specific characteristics of nonspecific low back pain. Clin Orthop. 1987 Apr;(217):266-80.

16. Spiker WR, Lawrence BD, Raich AL, Skelly AC, Brodke DS. Surgical versus injection treatment for injection-confirmed chronic sacroiliac joint pain. Evid-Based Spine-Care J. 2012;3(4):41-53.

17. Graham Smith A, Capobianco R, Cher D, Rudolf L, Sachs D, Gundanna M, et al. Open versus minimally invasive sacroiliac joint fusion: a multicenter comparison of perioperative measures and clinical outcomes. Ann Surg Innov Res. 2013;7(1):14. 18. INSITE Study Group, Whang P, Cher D, Polly D, Frank C, Lockstadt H, et al. Sacroiliac Joint Fusion Using Triangular Titanium Implants vs. NonSurgical Management: Six-Month Outcomes from a Prospective Randomized Controlled Trial. Int J Spine Surg [Internet]. 2015 Mar 5 [cited 2015 Mar 6];9. Available from: http://ijssurgery.com/

\section{$10.14444 / 2006$}

19. Ledonio C, Polly D, Swiontkowski MF, Cummings J. Comparative effectiveness of open versus minimally invasive sacroiliac joint fusion. Med Devices Evid Res. 2014 Jun 5;2014(7):187-93.

20. Heiney J, Capobianco R, Cher D. Systematic review of minimally invasive sacroiliac joint fusion using a lateral transarticular approach. Int J Spine Surg. 2015;9:Article 40.

21. Egund N, Olsson TH, Schmid H, Selvik G.

Movements in the sacroiliac joints demonstrated with roentgen stereophotogrammetry. Acta Radiol Diagn (Stockh). 1978;19(5):833-46.

22. Sturesson B, Selvik G, Uden A. Movements of the sacroiliac joints. A roentgenstereophotogrammetric analysis. Acta Orthop Scand Suppl.

1988;59(Suppl 227):89.

23. Goel VK, Grauer JN, Patel TC, Biyani A, Sairyo $\mathrm{K}$, Vishnubhotla $\mathrm{S}$, et al. Effects of charité artificial disc on the implanted and adjacent spinal segments mechanics using a hybrid testing protocol. Spine. 2005 Dec 15;30(24):2755-64.

24. Ivanov AA, Kiapour A, Ebraheim NA, Goel V. Lumbar fusion leads to increases in angular motion and stress across sacroiliac joint: a finite element study. Spine. 2009 Mar 1;34(5):E162-9.

25. Kiapour A, Abdelgawad AA, Goel VK, Souccar A, Terai T, Ebraheim NA. Relationship between limb length discrepancy and load distribution across the sacroiliac joint--a finite element study. J Orthop Res. 2012 Oct;30(10):1577-80.

26. Panjabi MM. Hybrid multidirectional test method to evaluate spinal adjacent-level effects. Clin Biomech Bristol Avon. 2007 Mar;22(3):257-65. 27. Soriano-Baron $\mathrm{H}$, Lindsey DP, RodriguezMartinez N, Reyes PM, Newcomb A, Yerby SA, et al. The Effect of Implant Placement on Sacroiliac Joint Range of Motion: Posterior vs Trans-articular. Spine. 2015 Feb 19;40(9):E525-30.

28. Pearcy M, Portek I, Shepherd J. Threedimensional $\mathrm{x}$-ray analysis of normal movement in the lumbar spine. Spine. 1984 Apr;9(3):294-7. 29. Pearcy MJ, Tibrewal SB. Axial rotation and lateral bending in the normal lumbar spine measured by three-dimensional radiography. Spine. 1984

Sep;9(6):582-7.

30. Yamamoto I, Panjabi MM, Crisco T, Oxland T. 
Three-dimensional movements of the whole lumbar spine and lumbosacral joint. Spine. 1989

Nov;14(11):1256-60.

\section{Disclosures}

This study was funded in part by SI-BONE, Inc. DPL and SAY are SI-BONE, Inc. employees and shareholders.

\section{Corresponding Author}

Derek P. Lindsey, M.S., SI-BONE, Inc., 3055 Olin Avenue, Suite 2200, San Jose, CA 95218. dlindsey@si-bone.com 